\title{
B-Acute Lymphoblastic Leukemia in a Follow-up Case of Breast Cancer
}

Sir,

Therapy-related leukemias are a well-known complication of the treatment of solid or hematological malignancies. Among solid malignancies, breast cancer is the most common cause of therapy-related leukemias. Therapy-related leukemias usually present within 5-7 years of the primary treatment. The majority of these leukemias are of the myeloid lineage, but therapy-related acute lymphoblastic leukemia (t-ALL) has been rarely described. Because of the rarity, the clinical and molecular markers have been poorly described in t-ALL. Hence, we report a case of B-acute lymphoblastic leukemia (ALL) developing in a patient of carcinoma breast on follow-up.

\section{Case Report}

We report a case of 40-year-old female, who was diagnosed with breast cancer, Stage IIIA (AJCC $7^{\text {th }}$ edition) with a hormonal profile of ER+ (8/8)/PR+ (6/8)/ Her2-. She received standard adjuvant chemotherapy with 4\#FEC (5-fluorouracil - $600 \mathrm{mg} / \mathrm{m}^{2}$, epirubicin - $75 \mathrm{mg} / \mathrm{m}^{2}$, cyclophosphamide - $600 \mathrm{mg} / \mathrm{m}^{2}$ ) and 4\#Docetaxel $\left(85 \mathrm{mg} / \mathrm{m}^{2}\right)$. After completion of chemotherapy, she underwent chest wall radiation 50 Gray/25\#/5 weeks. Along with radiotherapy, she was started on hormone therapy with tamoxifen. She completed her radiotherapy in August 2014 and after which was on regular follow-up with annual gynecology examination and mammogram.

She presented to us at the end of September 2018 with complaints of easy fatigability and generalized weakness. On clinical examination, she was pale with multiple, bilateral, level 2-3 cervical lymph nodes with hepatosplenomegaly (liver-4 cm and spleen- $6 \mathrm{~cm}$ below the costal margin).
On further evaluation, she had pancytopenia with suppression of all hematopoietic lineages. Her bone marrow aspiration repeatedly showed dry tap, and her bone marrow flow cytometry could not be done despite multiple attempts. However, bone her bone marrow biopsy showed large areas of fibrosis with immature cells (blasts) suggestive of B-ALL with CD20+, TDT+ [Figure 1]. With a final diagnosis of B-ALL, she was started on B-ALL (AYA) protocol with a further aim of HLA-Matched Allogenic Stem Cell Transplant. At present, she has completed the induction phase and her postinduction bone marrow examination is in complete remission.

\section{Discussion}

Therapy-related leukemias are one of the known and rare complications of anticancer drugs. Out of myeloid and lymphoid series, most of the cases of secondary leukemia are reported to be acute myeloid leukemia/myelodysplastic syndromes. t-ALL are among one of the rare causes of ALL. The incidence of t-ALL is difficult to decipher as the results of larger studies have been confounded by the inclusion of secondary ALL (s-ALL) [Table 1]. In most of the studies, both t-ALL and s-ALL account for $<1.5 \%-2.5 \%$ cases of ALL. ${ }^{[5,6]}$

Out of all anticancer drugs, alk'ylating agents and topoisomerase inhibitors are the most common drugs to be associated with therapy-related hematological malignancies. Therapy-related myeloid neoplasms have been reported to occur with a latency of 5-7 years with alkylating agents and 1-3 years with topoisomerase II inhibitors. ${ }^{[7]}$

In the recent study by Aldoss et al., ${ }^{[1]}$ the median time to develop t-ALL was 6.8 years. Breast cancer was the most common primary malignancy reported in their cohort. In

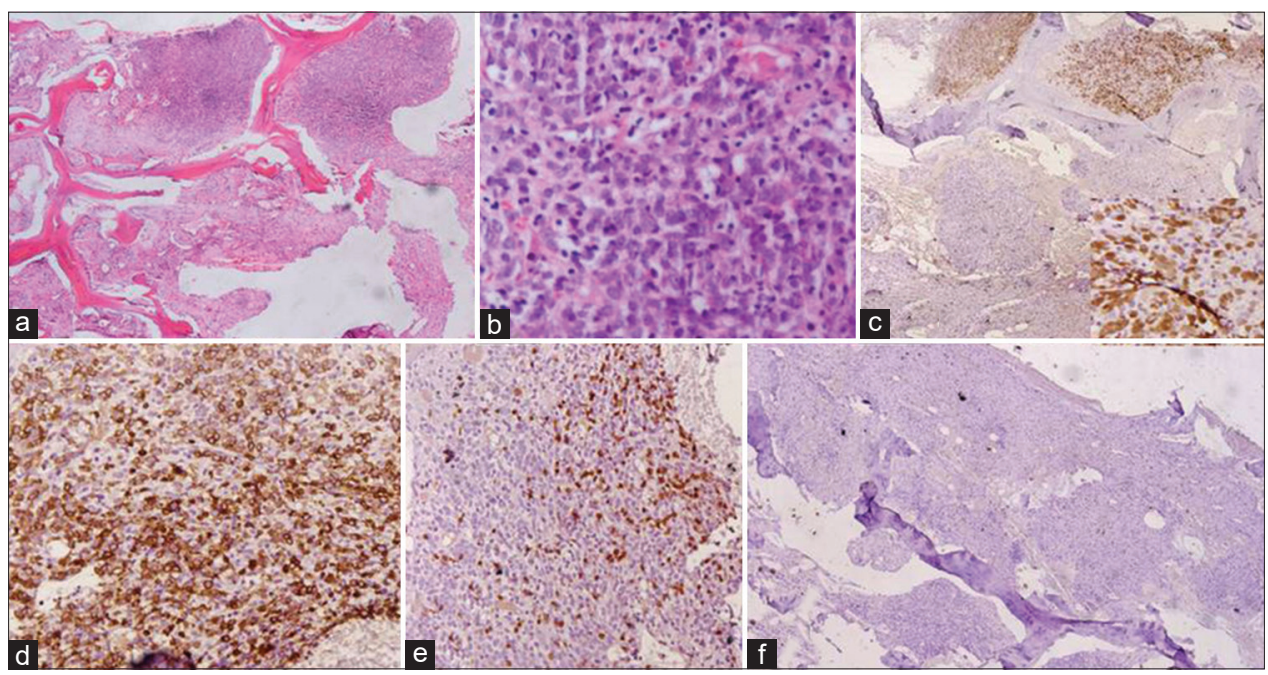

Figure 1: (a) Microphotograph shows bone marrow biopsy with large areas of fibrosis. (b) The well preserved space shows immature cells (blasts). The cell are immunopositive for TDT $([c] \times 200)$, CD20 ([d] $\times 200)$ while negative for CD3 $([e] \times 200)$ and MPO ([f] $\times 100)$ 
Table 1: Studies on therapy-related acute lymphoblastic leukemia (t-ALL) and secondary acute lymphoblastic leukemia (s-ALL)

\begin{tabular}{|c|c|c|c|c|c|c|c|}
\hline $\begin{array}{l}\text { Author } \\
\text { (year) }\end{array}$ & Sample size & $\begin{array}{l}\text { Frequency } \\
(\%)\end{array}$ & $\begin{array}{c}\text { Age } \\
\text { (years) }\end{array}$ & Most common solid tumor & $\begin{array}{c}\text { Interval to } \\
\text { develop ALL } \\
\text { (years) }\end{array}$ & $\begin{array}{l}\text { Cytogenetic } \\
\text { abnormality }\end{array}$ & OS (median) \\
\hline $\begin{array}{l}\text { Aldoss et al., } \\
2018^{[1]}\end{array}$ & $\begin{array}{l}\text { Total: } 1022 \\
\text { 93: t-ALL }\end{array}$ & 9.1 & 55 & Breast cancer $(25 \%)$ & 6.8 & $\begin{array}{c}\text { 29: Ph } \\
\text { 16: MLL } \\
\text { 5: Complex }\end{array}$ & $\begin{array}{c}2 \text { years OS: } \\
66.2 \%\end{array}$ \\
\hline $\begin{array}{l}\text { Rosenberg } \\
\text { et al., 2017 }\end{array}$ & $\begin{array}{c}\text { Total: } 14,470 \\
371(3 \%): \text { s-ALL } \\
\text { and } \mathrm{t}-\mathrm{ALL}\end{array}$ & 3 & $>70$ & Breast cancer $(21 \%)$ & 5.5 & - & - \\
\hline $\begin{array}{l}\text { Abdulwahab } \\
\text { et al., 2012 }\end{array}$ & 23: t-ALL & 6.9 & 51 & Breast $(40 \%)$ & 4 & $\begin{array}{c}\text { 8: MLL } \\
\text { 4: BCR-ABL }\end{array}$ & 13.6 years \\
\hline $\begin{array}{l}\text { Shivakumar } \\
\text { et al., 2008 }\end{array}$ & $\begin{array}{c}\text { 101: t-ALL } \\
\text { Age (years): } \\
<18: 29 \\
\text { 18-59: } 54 \geq 60: 18\end{array}$ & - & - & $\begin{array}{c}\text { Age (years): } \\
<\text { 18: Neuroblastoma } \\
\text { 18-59: Hodgkin's disease } \\
\geq 60 \text { : Breast and prostate } \\
\text { cancers }\end{array}$ & $\begin{array}{c}\text { Age (years): } \\
<18: 3 \\
\text { 18-59: } 2.2 \geq 60: \\
1.8\end{array}$ & $\begin{array}{l}\text { Most common } \\
\text { Age (years): } \\
\text { <18: MLL } \\
\text { 18-59: MLL } \\
\geq 60: \text { Normal }\end{array}$ & $\begin{array}{c}\text { Age (years): } \\
<18: 0.6 \\
\text { 18-59: } 0.5 \geq 60: \\
0.54\end{array}$ \\
\hline
\end{tabular}

ALL - Acute lymphoblastic leukemia; OS - Overall survival; t-ALL - Therapy related ALL; s-ALL - Secondary ALL; Ph - Philadelphia; MLL - Mixed lineage leukemia; BCR-ABL - Breakpoint cluster region-Abelson

their retrospective cohort, $83 \%$ of the patients had available molecular markers, and the most common abnormality was Philadelphia $(\mathrm{Ph})$ chromosome, followed by normal karyotype and mixed-lineage leukemia (MLL) gene rearrangement.

Our patient presented within 5 years of chemotherapy. She presented with typical symptoms of acute leukemia leading to symptoms of bone marrow failure. We could not identify any molecular abnormality of polymerase chain reaction and karyotyping studies because of the dry tap on bone marrow aspiration. This also raises a question of whether it was a therapy-related leukemia or an incidental finding of a breast cancer patient developing leukemia on follow up.

Therapy-related leukemias are biologically different from de novo ALL in terms of the clinical and molecular findings. The most consistent finding which has been reported among various series is the presence of molecular markers. ${ }^{[4,8]}$ The most consistent and common molecular markers associated with t-ALL are the presence of $\mathrm{Ph}$ chromosome and MLL gene rearrangement [Table 1].

It is difficult to arrive at a firm conclusion regarding the prognosis of patients with t-ALL because of the rarity of cases, but previous studies have reported t-ALL has a poor prognosis. Because of rarity, clinicians struggle to define a standard leukemia protocol, and the role of stem cell transplant has not been defined clearly.

According to the literature, data are sparse regarding ALL occurring as a therapy-related leukemia in a follow-up case of breast cancer. We could find only one case series of five patients published from India. ${ }^{[9]}$ In which of five patients, only one had t-ALL. Hence, we report this case to increase the awareness of the same and the need for a high index of suspicion and the importance of regular follow-up even after remission of the primary malignancy.

The large scale database search is required to know the exact incidence and the outcomes of patients with t-ALL in Indian patients.

Financial support and sponsorship

Nil.

\section{Conflicts of interest}

There are no conflicts of interest.

\section{Arun Garg1', Ajay Gogia1, Saumyaranjan Mallick ${ }^{2}$, Ritu Gupta ${ }^{3}$}

${ }^{1}$ Department of Medical Oncology, All India Institute of Medical Sciences, New Delhi, India, ${ }^{2}$ Department of Pathology, All India Institute of Medical Sciences, New Delhi, India, ${ }^{3}$ Department of Laboratory Oncology, Dr. B.R.A.IRCH, All India Institute of Medical Sciences,

New Delhi, India

Address for correspondence: Dr. Ajay Gogia,

Department of Medical Oncology, All India Institute of Medical Sciences, New Delhi, India.

E-mail:ajaygogia@gmail.com

Submitted: 23-Jan-2019

Revised: 28-Feb-2019

Accepted: 06-Oct-2019

Published: 24-Apr-2020

\section{References}

1. Aldoss I, Stiller T, Tsai NC, Song JY, Cao T, Bandara NA, et al. Therapy-related acute lymphoblastic leukemia has distinct clinical and cytogenetic features compared to de novo acute lymphoblastic leukemia, but outcomes are comparable in transplanted patients. Haematologica 2018;103:1662-8.

2. Rosenberg AS, Brunson A, Paulus JK, Tuscano J, Wun T, 
Keegan $\mathrm{TH}$, et al. Secondary acute lymphoblastic leukemia is a distinct clinical entity with prognostic significance. Blood Cancer J 2017;7:e605.

3. Abdulwahab A, Sykes J, Kamel-Reid S, Chang H, Brandwein JM. Therapy-related acute lymphoblastic leukemia is more frequent than previously recognized and has a poor prognosis. Cancer 2012;118:3962-7.

4. Shivakumar R, Tan W, Wilding GE, Wang ES, Wetzler M. Biologic features and treatment outcome of secondary acute lymphoblastic leukemia - A review of 101 cases. Ann Oncol 2008;19:1634-8.

5. Pagano L, Pulsoni A, Mele L, Leone G. Clinical and epidemiological features of acute lymphoblastic leukemia following a previous malignancy. Leuk Lymphoma 2000;39:465-75.

6. Ishizawa S, Slovak ML, Popplewell L, Bedell V, Wrede JE, Carter $\mathrm{NH}$, et al. High frequency of pro-B acute lymphoblastic leukemia in adults with secondary leukemia with $11 \mathrm{q} 23$ abnormalities. Leukemia 2003;17:1091-5.

7. Hawkins MM, Wilson LM, Stovall MA, Marsden HB, Potok MH, Kingston JE, et al. Epipodophyllotoxins, alkylating agents, and radiation and risk of secondary leukaemia after childhood cancer. BMJ 1992;304:951-8.

8. Tang G, Zuo Z, Thomas DA, Lin P, Liu D, Hu Y, et al. Precursor B-acute lymphoblastic leukemia occurring in patients with a history of prior malignancies: Is it therapy-related?
Haematologica 2012;97:919-25.

9. Bhatia P, Das R, Ahluwalia J, Malhotra P, Varma N, Varma S, et al. Acute leukemia/myelodysplastic syndrome as a sequelae of carcinoma breast: A report of five cases from North India. Indian J Pathol Microbiol 2009;52:167-70.

This is an open access journal, and articles are distributed under the terms of the Creative Commons Attribution-NonCommercial-ShareAlike 4.0 License, which allows others to remix, tweak, and build upon the work non-commercially, as long as appropriate credit is given and the new creations are licensed under the identical terms.

\begin{tabular}{|l|l|}
\hline \multicolumn{2}{|c|}{ Access this article online } \\
\hline Quick Response Code: & Website: \\
& www.ijmpo.org \\
\cline { 2 - 2 } & DOI: \\
\hline
\end{tabular}

How to cite this article: Garg A, Gogia A, Mallick S, Gupta R. B-acute lymphoblastic leukemia in a follow up case of breast cancer. Indian J Med Paediatr Oncol 2020;41:99-101.

()2020 Indian Journal of Medical and Paediatric Oncology | Published by Wolters Kluwer - Medknow 